\title{
KEBIJAKAN PERLINDUNGAN SOSIAL DAN PENCEGAHAN RETRAFFICKING BAGI ANAK DI PROVINSI JAWA BARAT
}

\author{
Oleh \\ Binahayati Rusyidi, Eva Nuriyah, \& Lenny Meilani
}

\begin{abstract}
ABSTRAK
Jawa Barat merupakan salah satu provinsi asal terbesar dari mana anak menjadi korban perdagangan orang. Kebijakan perlindungan anak yang bertujuan mencegah, menangani korban serta mencegah terjadinya pengulangan (retrafficking) menjadi suatu keniscayaan. Penelitian kualitatif ini menganalisa kebijakan pemerintah provinsi Jawa Barat dalam perlindungan sosial trafficking anak. Informan adalah perwakilan dari kelembagaan pemerintah yang memiliki tugas untuk merancang dan melaksanakan program perlindungan anak yaitu Dinas Sosial, BPPAKB, UPPA Polda Jabar, dan Dinas Pendidikan. Pengumpulan data dilakukan melalui wawancara dan studi dokumentasi. Data analisis dilakukan secra kualitatif berdasarkan kerangka analisa kebijakan sosial dari Gilbert \& Terrel yang memfokuskan pada: basis of allocation, nature of provision, delivery system, and finance methods.

Penelitian menemukan bahwa Jawa Barat telah memiliki peraturan daerah yang memayungi perlindungan sosial anak. Program-program pencegahan bersifat universal sedangkan program bersifat selektif ditemukan mendominasi arah perlindungan sosial berupa penanganan, rehabilitasi korban anak, serta pemberdayaan keluarga umumnya yang didistribusikan meliputi protective regulations, layanan profesional dan in-kind. Pelaksanaan kebijakan dilakukan secara mandiri maupun koordinatif lintas lembaga namun belum memberikan perhatian memadai pada aspek monitoring dan evaluasi. Sumber pendanaan umumnya berasal dari APBN dan APBD masih dianggap kurang memadai. Sementara itu pendanaan yang melibatkan keikutsertaan lembaga nonpemerintah, khususnya duania usaha masih terbatas.

Pengembangan kebijakan yang berorientasi pencegahan, penguatan kapasitas dan ketahanan keluarga, diversifikasi pendanaan serta penerapan monitoring dan evaluasi yang optimal agar dapat dilaksanakan untuk efektivitas perlindungan sosial terkait perdagangan anak.
\end{abstract}

\section{Kata kunci: perdagangan anak, perlindungan sosial, kebijakan sosial}

\section{LATAR BELAKANG}

Permasalahan kesejahteraan anak semakin kompleks sejalan dengan perkembangan tantangan kehidupan dalam masyarakat. Pada awalnya, di seputar dekade 80 dan 90-an, isu kesejahteraan anak berkisar pada masalah anak cacat, yatim piatu, dan anak jalanan. Sejak awal tahun 2000, salah satu tantangan terkini perlindungan anak terkait dengan perdagangan anak (child trafficking). Jawa Barat merupakan provinsi yang menduduki peringkat teratas dalam kasus trafficking secara umum, termasuk anak.

Selama lima tahun terakhir, Badan Reserse dan Kriminal Kepolisian RI (Bareskrim Polri, 2013) menangani 646 kasus perdagangan manusia, dengan total 1446 korban. Sebanyak 708 orang diantaranya perempuan dewasa dan 312 orang masuk 
kategori anak-anak. Berdasarkan daerah asal korban, data dari International Organization for Migration (2012) menempatkan Jawa Barat sebagai daerah asal terbesar korban perdagangan manusia, yang di dalamnya juga termasuk korban berusia di bawah 18 tahun. Trafficking menimbulkan dampak yang signifikan terhadap kualitas hidup dan tumbuh kembang anak. Dampak tersebut timbul sebagai akumulasi kondisi dan perlakuan kekerasan serta eksploitatif yang dapat terjadi sejak tahap perekrutan, penampungan, pengiriman, dan atau penempatan. Anak yang diperdagangkan tercabut haknya untuk menerima pendidikan, bermain, bersosialisasi, serta terbebas dari tindak kekerasan. Mereka juga banyak mengalami gangguan-gangguan psikologis termasuk gangguan pasca -trauma, depresi, daan sebagainya. Khusus bagi mereka yang dilacurkan, korban perdagangan anak berisiko tinggi untuk menderita penyakit menular seksual dan mengalami kehamilan yang tidak dikehendaki. Secara sosial, anak mengalami rasa malu yang luar biasa atau rasa bersalah yang terus menghantui karena menganggap dirinya tidak berarti, tidak berharga atau kotor (International Organization for Migration, 2012).

Anak korban trafficking berhak untuk mendapatkan perlindungan khusus dan pertolongan guna mengatasi berbagai dampak fisik, kesehatan dan psikologis yang dialaminya. Undang-undang Nomor 23 Tahun 2002 tentang Perlindungan Anak megatur secara khusus tugas negara dan masyarakat dalam perlindungan anak yang " bertujuan untuk menjamin terpenuhinya hak-hak anak agar dapat hidup, tumbuh, berkembang dan berpartisipasi secara optimal sesuai dengan harkat dan martabat kemanusiaan, serta mendapat perlindungan dari kekerasan dan diskriminasi, demi terwujudnya anak Indonesia yang berkualitas, berakhlak mulia dan sejahtera".

Indonesia telah memilki perangkat perundangan dan kelembagaan yang bertujuan untuk mencegah tindak perdagangan anak dan perlindungan hak-hak anak termasuk di dalamnya Undang-undang Pemberantasan
Tindak Pidana Perdagangan Orang, ratifikasi Konvensi Hak Anak Tahun 1990, Rencana Aksi Penanggulangan Perdagangan Anak, serta pembentukan Komisi Perlindungan Anak untuk tujuan pengawasan pemenuhan hak-hak anak. Di tingkat daerah, berbagai bentuk kebijakan perlindungan anak khususnya anak korban trafficking juga telah dikembangkan.

Namun demikian perlu suatu kajian yang menganalisis kebijakan daerah dalam perlindungan anak korban trafficking untuk melihat sejauh mana kebijakan tersebut secara explisit merespon kebutuhan anak korban trafficking dan mencegah terjadinya retrafficking terhadap korban. Dalam praktek pekerjaan sosial, kebijakan sosial merupakan produk yang dijadikan pedoman dalam pembentukan, pengembangan atau memperluas pelayanan sosial, suatu kelompok, organisasi (Kahn, 1973:69; Gilbert \& Terrel, 2008). Kebijakan sosial perlindungan anak korban perdagangan manusia perlu menjamin pemenuhan kebutuhan anak dalam rangka mengurangi potensi dampak negatif yang berkelanjutan serta memperkuat pencegahan terjadinya retrafficking terhadap korban. Dengan adanya berbagai kebijakan yang telah ditetapkan oleh Provinsi Jawa Barat khususnya dalam menangani masalah perdagangan anak perlu dilakukan analisis kebijakan sosial dalam perlindungan sosial anak korban trafficking dan pencegahan trafficking yang telah dilakukan oleh pemerintah Provinsi Jawa Barat.

\section{TINJAUAN KONSEPTUAL}

Pengertian anak didefinisikan secara berbeda dalam berbagai peraturan di tingkat internasional dan nasional. Keberagaman pendefinisian tersebut umumnya terkait pada batasan usia apa seorang individu dikategorikan sebagai anak. Convention on the Rights of the Child (1989) yang telah diratifikasi pemerintah Indonesia melalui Kepres No. 39 Tahun 1990 disebutkan bahwa anak adalah mereka yang berusia 18 tahun ke bawah. Indonesia menambahkan dimensi sosial pada definisi anak seperti tercantum 
dalam Undang-undang RI Nomor 4 Tahun 1979 tentang Kesejahteraan Anak yang menyebutkan bahwa anak adalah mereka yang belum berusia 21 tahun dan belum menikah.

Merujuk pada UN Protocol to Prevent, Suppress and Punish Trafficking in Person, Especially Woman and Children tahun 2000, Undang-Undang Pemberantasan Tindak Pidana Perdagangan Orang Republik Indonesia merumuskan adanya 3 dimensi perdagangan manusia yaitu: adanya kegiatan berupa "... pengrekrutan, pengangkutan, pemindahan, penampungan atau penerimaan manusia ..." ; cara melalui "... ancaman atau penggunaan kekerasan atau bentuk lain pemaksaan, penculikan, pemalsuan, penipuan, penyalahgunaan kekuasaan atau posisi rentan atau pemberian atau penerimaan pembayaran atau manfaat guna mendapatkan persetujuan seseorang yang memiliki kuasa atas orang lain..." serta tujuan eksploitasi. Eksploitasi meliputi, setidaknya, eksploitasi prostitusi terhadap orang lain atau bentuk lain eksploitasi seksual lainnya, kerja atau layanan paksa, perbudakan atau praktek yang serupa dengan perbudakan, penghambaan atau pengambilan organ tubuh..." Pemenuhan ketiga unsur di atas diperlukan dalam penentuan kasus perdagangan manusia. Namun khusus terkait dengan trafficking anak, unsur cara tidak dipertimbangkan karena anak secara legal dianggap tidak dapat memberikan kesediaan baik dengan cara dipaksa/dibohongi/dikuasai maupun secara sukarela.

Penyebab perdagangan manusia terkait dengan berbagai faktor resiko dan kerentanan yang bersumber dari lingkungan internal dan eksternal korban baik yang terait dengan dimensi kehidupan lokal maupun global. Berbagai studi menunjukkan kemiskinan, rendahnya tingkat pendidikan, dan tingginya pengangguran seringkali mengurangi daya kritis dan daya tolak masyarakat terhadap tawaran-tawaran kerja yang sebenarnya bersifat membohongi dan eksploitatif (Akee dkk, 2009; Sofyan, 2004). Faktor terkait disfungsi sosial keluarga juga menjadi sumber kerentanan perdagangan anak. Pada beberapa kasus, ketidakberfungsian keluarga secara sosial melemahkan fungsi pengawasan dan pendidikan keluarga terhadap anak. Beberapa penelitian di Indonesia menemukan bahwa pada berbagai kasus, orangtua atau keluarga menjadi pelaku trafficking baik dengan sengaja atau tidak sengaja "mendorong" atau "membiarkan"anak untuk untuk bekerja di sektor-sektor eksploitatif termasuk pelacuran atau menjadi sasaran perekrutan para pelaku trafficking (Puslitbang Gender dan Anak LPPM Unpad, 2012)..

Perlindungan sosial dapat dipahami sebagai suatu langkah-langkah untuk mengatasi kemiskinan dan kerentanan sosial ekonomi termasuk kesehatan, pendidikan dan gizi. Perlindungan sosial juga dimaksudkan untuk meningkatkan kesiapan anggota masayarakat dalam menghadapi kondisikondisi sosial ekonomi yang tidak pasti di masa mendatang. Seperti yang dikemukakan oleh UNICEF, perlindungan sosial adalah:

a set of public actions which address not only income poverty and economic shocks, but also social vulnerability, thus taking into account the interrelationship between exclusion and poverty. Through income or in-kind support and programmes designed to increase access to services (such as health, education and nutrition), social protection helps realize the human rights of children and families. Social protection strategies are also a crucial element of effective policy responses to adverse economic conditions, addressing not only vulnerabilities caused or exacerbated by recent crises but also increasing preparedness to future uncertainty.

Menurut UNICEF, terkait dengan anak, perlindungan sosial harus lebih sensistif terhadap anak. Perlindungan sosial yang sensitive anak tidak hanya menguntungkan keluarga tetapi juga komunitas dan pembangunan nasional secara keseluruhan. Perlindungan sosial yang sensitif anak mengurangi pengaruh kemiskinan terhadap keluarga, memperkuat keluarga dalam 
pelaksanaan peran pengasuhan /perawatan anak, dan meningkatkan akses terhadap pelayanan dasar untuk kelompok-kelompok miskin dan terpinggirkan.

Prinsip-prinsip di dalam menyusun, mengimplementasikan dan mengevaluasi perlindungan sosial yang sensiti anak meliputi:

1. Mencegah dampak negative terhadap anak dan mengurangi atau menghiilangkan resiko sosial yang secara langsung mempengaruhi kehidupan anak

2. Melakukan intervensi secepat mungkin ketika anak mengalami kondisi-kondisi yang berisiko dalam rangka mencegah kerusakan atau bahaya yang tidak bisa diperbaiki terhadap anak

3. Mempertimbangkan resiko-resiko dan kerentanan yang khusus terkait dengan usia dan gender sepanjang tahap kehidupan anak

4. Menghilangkan dampak krisis, penyingkiran dan kemiskinan pada keluarga, menyadari bahwa keluarga yang memelihara anak membutuhkan dukungan untuk menjamin kesetaraan kesempatan

5. Membangun pelayanan-pelayanan khusus untuk menjangkau anak yang berada dalam kondisi rentan dan tersingkirkan, termasuk anak yang tidak mendapatkan perawatan orangtua atau terpinggirkan dalam keluarga atau komunitas karena atribut gender, kecacatan, etnik, dan sebagainya.

6. Melibatkan suara dan pendapat anak dalam memahami dan menyusun sistem dan program perlindungan sosial.

Kebijakan sosial adalah seperangkat tindakan, kerangka kerja, petunjuk, rencana , peta atau strategi, yang dirancang untuk menterjemahkan visi politis pemerintah atau lembaga pemerintah ke dalam program dan tindakan untuk mencapai tujuan tertentu di bidang kesejahteraan sosial (Suharto, 2008: 82). Kebijakan sosial menjadi perhatian dari ahli sosial berkaitan dengan isu yang berhubungan dengan pemerataan sosial (social equity) atau keadilan sosial (social justice) serta dampaknya terhadap proses perubahan atau perkembangan sosial (Chambers \& Wedel, 2005).

Penelitian ini merupakan bentuk kajian produk perlindungan anak korban tindak kekekarasan perdagangan manusia. Adapun kerangka yang akan menuntun analisa kebijakan produk yang akan digunakan merujuk kepada kerangka analisa kebijakan kesejahteraan sosial yang mencakup dimensidimensi sebagai berikut (Gilbert \& Terrel, 2008):

\section{a. The Basis of Social Allocation}

Pertanyaan mendasar dalam dimensi pertama terkait apakah kebijakan bersifat universal atau selektif? Siapakah penerima manfaat kebijakan yang menjadi sasaran implementasi kebijakan? Apa dasar penentuan eligibilitas sasaran yang digariskan dalam kebijakan? Terkait dengan perlindungan anak korban perdagangan manusia, perlu dikaji apakah sasaran kebijakan bersifat umum, misalnya mencakup anak korban, korban dan keluarga, korban, keluarga dan lingkungan sekitarnya? Apa asumsi-asumsi yang mendasari penentuan penerima manfaat tersebut?

b. The Nature of Social Provision

Pertanyaan mendasar dalam dimensi kedua berhubungan dengan apa tipe manfaat yang disediakan bagi sasaran? Apakah bentuk manfaat terkait dengan pemberian barang, jasa, pelayanan, kesempatan, dan lain-lain? Seberapa banyak dan seberapa lama manfaat tersebut disediakan? Nilai atau asumsi apa yang mendasari penentuan tipe/bentuk manfaat diberikan sedangkan yang lain tidak?

c. The Design of the Delivery System

Pertanyaan mendasar dari dimensi ketiga terkait bagaimana sistem pendistribusian pelayanan? Bagaimana sistem pendistribusian dapat menjamin akses penerima manfaat? Apakah terpusat pada satu kelembagaan atau tersebar dalam berbagai kelembagaan di berbagai wilayah?

$d$. The Mode of Finance

Pertanyaan mendasar dari dimensi keempat terkait dengan sumber-sumber pendanaan? 
Bagaimana pendanan tersebut dialokasikan ke penyedia pelayanan?

\section{METODE PENELITIAN}

Desain penelitian ini merupakan penelitian natural dengan menggunakan pendekatan kualitatif untuk mendiskripsikan fenomena yang diteliti dengan menggunakan teknik studi kasus. Unit analisa utama penelitian adalah kelembagaan pemerintah yang merancang dan melaksanakan kebijakan perlindungan sosial anak korban trafficking di Provinsi Jawa Barat yang dipilih secara purposive yaitu Badan Perlindungan dan pemberdayaan Perempuan dan Anak, Pengendalian Kependudukan dan Keluarga Berencana, Dinas Sosial Provinsi, POLDA Jabar dan Dinas Pendidikan tingkat Provinsi Jawa Barat.

Teknik pengumpulan terdiri atas studi dokumentasi atau desk review terhadap kebijakan/program perlindungan anak korban perdagangan manusia di Provinsi Jawa Barat, terutama yang terkait dengan keberadaan dan konten kebijakan/program pemenuhan kebutuhan korban dan pencegahan korban untuk diperdagangkan kembali (retrafficked). Inti dari studi dokumentasi adalah untuk mengidentifikasi eksistensi dan konten dari kebijakan/program perlindungan anak korban perdagangan. Selain itu dilakukan juga wawancara mendalam untuk memperdalam hasil kajian dokumentasi dan pelaksanaannya.Data dianalisis dimulai dengan menelaah seluruh data yang tersedia dari berbagai sumber, hasil desk review, hasil wawancara mendalam, pengolahan dokumen penunjang dan sebagainya, menyortir, mengkategorikan, menghubungkan data dan informasi yang ada dan akhirnya membuat kesimpulan-kesimpulan hasil penelitian.

\section{HASIL}

\section{Kebijakan Sosial Perlindungan Anak} Korban Trafficking di Provinsi Jawa Barat

Kebijakan perlindungan anak korban trafficking di Jawa Barat tidak disusun secara khusus namun terangkum dalam Peraturan Daerah Jawa Barat No. 3/2008 tentang
Pencegahan dan Penanganan Korban Perdagangan Orang di Jawa Barat. Salah satu pertimbangan yang mendasari Perda tersebut mengingat Jawa Barat merupakan daerah asal dan atau daerah transit perdagangan orang termasuk anak. Komponen kebijakan berupa

a. Pencegahan preemtif melalui peningkatan jumlah dan mutu pendidikan formal dan informal bagi masyarakat, aksesibilitas untuk mendapatkan pendidikan, pelatihan, pendanaan, peningkatan pendapatan dan pelayanan sosial, perluasan lapangan kerja, peningkatan partisipasi dan kepedulian masyarakat serta pemberdayaan dan penyadaran masyarakat. Pelaksanaan kebijakan pencegahan preemtif merupakan peran dari perangkat daerah yang tugas pokok dan fungsinya di bidang sosial, pendidikan, ketenagakerjaan dan perekonomian

b. Pencegahan preventif

c. Pencegahan perdagangan anak termasuk di dalamnya pencegahan pekerjaan terburuk anak.

d. Penanganan korban perdagangan orang yang dilakukan perangkat pemerintah daerah di bidang sosial, pendidikan dan kesehatan yang meliputi :

-penjemputan, penampungan dan pendampingan terhadap korban sesuai dengan asal domisili Jawa Barat; koordinasi dengan pemerintah kabupaten/ kota tempat domisili korban untuk proses pemulangan bagi korban peragangan ke daerah asalnya; pelaporan tentang adanya tindak pidana perdagangan orang kepada aparatur penegak hukum yang berwenang sesuai dengan peraturan perundangundangan dan-pemberian bantuan hukum dan pendampingan bagi korban.

e. Rehabilitasi yang mewajibkan pemerintah daerah untuk melakukan upaya-upaya: pemulihan kesehatan fisik dan psikis bagi korban perdagangan orang;reintegrasi korban ke keluarganya atau lingkungan masyarakatnya; dan pemberdayaan ekonomi dan atau pendidikan terhadap korban. 


\section{Kebijakan Dinas Sosial Provinsi Jawa Barat}

Terkait penanganan perdagangan manusia, sejalan dengan tugas pokok dan fungsi Kementrian Sosial, maka Dinas Sosial Provinsi Jawa Barat mengemban tugas terkait rehabilitasi, pemulangan, reintegrasi, dan pemberdayaan korban. Program rehabilitasi sosial bertujuan untuk membantu meringankan, melindungi serta memulihkan kondisi fisik, psikologis, sosial dan spiritual korban tindak pidana perdagangan orang sehingga mampu menjalankan fungsi sosialnya kembali secara wajar. Rehabilitasi sosial diperlukan oleh korban mengingat proses dan kegiatan-kegiatan yang terkait perdagangan orang, mulai dari perekrutan, pemindahan, hingga penempatan korban umumnya sarat dengan tindakan kekerasan dan eksploitasi sehingga sangat memungkinkan untuk menimbulkan trauma psikis dan sosial bagi korban. Lamanya kegiatan rehabilitasi psikososial tergantung dari dampak perdagangan manusia terhadap kondisi psiko-sosial korban; mulai dari beberapa hari hingga 6 bulan bahkan satu tahun melalui P2TP2A Provinsi.

Bentuk-bentuk kegiatan rehabilitasi sosial berupa terapi psikososial berupa pemberian konseling, terapi psikologis, pembinaan rohani, serta aktivitas-aktivitas fisik dan sosial lainnya. Para korban juga menjalani program edukasi berupa peningkatan kesadaran akan bentuk, modus dan bahaya trafficking. Edukasi ini dimaksudkan agar para korban lebih waspada dan dapat menghindari terulangnya kejadian serupa. Program edukasi juga diharapkan dapat menjadikan para korban mampu memberikan pemahaman tentang praktek dan bahaya trafficking kepada lingkungan terdekatnya berdasarkan pengetahuan dan pengalaman yang mereka dapatkan secara langsung.Pendanaan rehabilitasi bersumber dari APBN dan APBD.

Pemulangan korban umumnya merupakan kegiatan mengembalikan korban trafficking ke keluarga asalnya atau ke keluarga pengganti korban. Terkait dengan pemulangan korban, Dinas Sosial Provinsi terlibat dalam satu atau lebih aktivitas di bawah ini: 1) menjemput korban perdagangan manusia asal Jawa Barat yang menjadi korban perdagangan manusia di wilayah di luar Jawa Barat ( beda provinsi atau luar negeri) dan mengembalikannya kepada keluarga masingmasing dan atau 2) membawa korban perdagangan asal Jawa Barat ke wilayah Kabupaten/Kota asal di wilayah Jawa barat untuk mendapatkan pelayanan atau berkumpul dengan keluarga asalnya; dan atau 3)mengembalikan korban yang sudah menjalani rehabilitasi untuk kembali berkumpul bersama dengan keluarganya. Dalam program pemlangan korban, terutama penjemputan korban, Dinas Sosial Provinsi Jawa Barat umumnya berkoordinasi dan bekerjasama dengan BPPKB Provinsi, P2TP2A provinsi, serta unsur kepolisian.Terkait dengan korban anak, pengembalian kepada keluarga asal dianggap merupakan pengejawantahan prinsip perlindungan kepentingan terbaik anak. Namun dalam kondisi-kondisi tertentu di mana orangtua/keluarga dinilai tidak mampu untuk menjalankan fungsinya secara minimal, maka anak bisa dipindahkan pengasuhannya kepada keluarga pengganti. Pengembalian anak kepada keluarga adalah untuk menjamin tetap terpenuhinya kebutuhan anak akan pendidikan, pengasuhan dan kasih sayang dari keluarganya. Biaya pemulangan sepenuhnya ditanggung oleh Dinas Sosial.

Bersamaan dengan kegiatan pemulangan, korban juga dibantu untuk mendapatkan akses Jamkesmas, terutama jika keluarganya tergolong tidak mampu. Tujuannya adalah agar korban tetap mmendapatkan kesempatan untuk mengakses fasilitas kesehatan dasar yang dibutuhkan untuk mengatasi dampak kesehatan yang muncul kemudian akibat trafficking yang dialaminya. Selanjutnya, para keluarga korban trafficking juga mendapatkan sejenis penyuluhan terkait dengan pencegahan trafficking dan pemberian dukungan kepada korban. Walaupun demikian, kegiatan ini 
bukanlah merupakan kegiatan yang terstruktur sehingga lebih didasarkan pada pendekatan personal.

Reintegrasi bertujuan mengintegrasikan korban ke lingkungan sosial termasuk keluarga dan lingkungan yang lebih luas melalui pelaksanaan fungsi-fungsi sosialnya secara wajar sebagai anggota masyarakat. Untuk korban anak, kegiatan reintegrasi dapat dilakukan melalui 2 kegiatan utama yaitu 1) pendidikan formal dan 2) pendidikan luar sekolah berupa pelatihan keterampilan. Kegiatan reintegrasi ini dilakukan dengan tetap memperhatikan aspirasi dan keinginan anak korban serta pertimbangan-pertimbangan dari keluarga untuk kepentingan terbaik anak.

Program untuk mengembalikan korban anak ke lembaga pendidikan formal bertujuan adalah untuk menjamin terpenuhinya hak korban anak akan pendidikan. Pada banyak kasus, anak korban trafficking adalah siswa/pelajar yang terpaksa berhenti dari sekolahnya karena dipekerjakan/dieksploitasi oleh pelaku perdagangan manusia. Jika anak berasal dari keluarga tidak mampu, maka Dinas Sosial akan berkoordinasi dengan Dinas Pendidikan agar keluarga anak dibebaskan dari kewajiban membayar biaya pendidikannya.

Selain itu, jika anak korban trafficking memutuskan tidak melanjutkan pendidikan, maka Dinas Sosial dapat menawarkan program pelatihan keterampilan kepada korban anak melalui program Bina Remaja. Tujuan dari pelatihan Bina remaja adalah mempersiapkan anak agar bisa mandiri melalui dunia kerja (mendapatkan pekerjaan atau membuka lapangan kerja baru. Keterampilan yang dimiliki anak diharapkan dapat mempercepat pemulihan trauma dan meningkatkan rasa percaya diri korban, mempercepat proses reintegrasi korban, dan mengurangi kerentanan korban untuk kembali dijadikan korban. Banyak korban trafficking terjebak imingiming pekerjaan dan penghasilan yang tinggi dari para pelaku

Bina Remaja memberikan pendidikan keterampilan sesuai dengan minat dan bakat anak, diantaranya perbengkelan, pengolahan pangan, tata kecantikan, dan sebagainya.
Selama pelatihan anak akan mendapatkan asrama, dukungan alat/bahan, fasilitas magang, dan modal awal berupa peralatan untuk memulai usaha. Semua fasilitas selama pelatihan diberikan secara cumacuma.Pelatihan dilaksanakan di balai Bina remaja selama kurang lebih 4 (empat) bulan. Program Bina remaja dilaksanakan sebanyak 2 angkatan per tahun dengan peserta rata-rata 60 orang anak per angkatan. Saat ini Dinas Sosial tengah menjajaki kerja sama dengan beberapa perusahaan swasta untuk menyediakan fasilitas pelatihan dan penempatan peserta Bina remaja di seluruh wilayah Indonesia.

Dinas Sosial juga melakukan penguatan ekonomi keluarga.Bantuan dana melalui program Usaha Ekonomi Produktif (UEP) merupakan salah satu strategi untuk meningkatkan ketahanan ekonomi keluarga anak korban trafficking, terutama dengan tujuan untuk mencegah terjadinya kembali trafficking pada korban. Setiap tahun Dinas Sosial Provinsi akan mengajukan sejumlah dana UEP ke Kementrian Sosial. Pengajuan didasarkan pada kebutuhan yang diajukan oleh Dinas Sosial Kabupaten/Kota. Pendanaan UEP berasal dari APBN dan APBD Jawa Barat.

Dalam UEP, keluarga korban mendapatkan pelatihan usaha ekonomi produktif dan bantuan dana yang diberikan dalam bentuk barang untuk modal usaha. Jumlah dana yang diterima sekitar 3 juta rupiah dan bersifat bantuan sosial sehingga penerima tidak diwajibkan untuk mengembalikan bantuan yang sudah diterima kepada Dinas Sosial. Peserta UEP dapat memilih usaha produktif yang sesuai dengan minat dan kemampuan masing-masing, di antaranya pengolahan pangan, jahit, toko kelontong, dan sebagainya. Penerima UEP mendapatkan pendampingan dari petugas yang bertugas memantau perkembangan usaha yang dijalani dan perkembangan kehidupan keluarga peserta. Namun menurut Dinas Sosial Provinsi Jawa Barat, pendampingan kurang berjalan dengan baik sehingga usaha peserta tidak bertahan dan produktif. Modal usaha berupa barang tersebut kadangkala dijual atau dipakai 
oleh penerima untuk menutupi kebutuhan sehari-hari.

\section{Kebijakan Dinas Pendidikan Jawa Barat}

Kebijakan Dinas Pendidikan Jawa Barat tidak terkait langsung dengan penanganan korban tetapi program-program yang bersifat pencegahan. Namun demikian program terkait pencegahan trafficking tidak berdiri sendiri melainkan diintegrasikan dengan kegiatankegiatan Pengarusutamaan Gender di Jawa Barat. Adapun kegiatan-kegiatan terkait PUG tersebut meliputi: a) Sosialisasi PUG Tingkat Pemangku Kebijakan se Jawa Barat; b)Pelatihan PSBG tingkat SD, SMP, SMA/SMK se Jawa Barat; c) Bantuan Sosial PUG Tingkat SD, SMP, SMA/SMK untuk sosialiasasi dan penyusunan silabus tingkat satuan pendidikan $\mathrm{Rp} 15.000 .000,00 ; \mathrm{d}$ ) Pembuatan leaflet, poster dan buku pedoman PUG; e) Penyusunan profil gender; f) Penyusunan position paper PUG bidang pendidikan Provinsi Jawa Barat; g)Penyusunan dan penggandaan buku Keterkaitan Sistem Keluarga dan Sekolah Terhadap Kenakalan Pelajar; h)Penyusunan dan penggandaan buku Analisis Bahan Ajar Yang Responsif Gender Tingkat SD, SMP, dan SMA/SMK; i) Bantuan keuangan untuk Piloting Pokja Gender dan Sosialisasi pada 5 kabupaten se Jawa Barat (Kabupaten Tasikmalaya, Kabupaten Subang, Kabupaten Sukabumi, Kabupaten Karawang, dan Kota Bogor); j)Bantuan keuangan untuk 21 kabupaten/kota untuk pembentukan Pokja Gender Bidang Pendidikan Tingkat Kabupaten/Kota se Jawa Barat; k) Penguatan Jejaring PUG (Stakeholder Bidang Pendidikan); 1) Pembentukan Pokja Gender Tingkat Provinsi; m) Pelatihan PPRG Bagi Pengelola PUG Tingkat Kabupaten/Kota (PNFI dan Bagian Perencanaan); n)Kerjasama dan kemitraan dengan PSW UNPAD, PSW UPI, PSW IPB dan BPPKB Provinsi Jawa Barat; o)Evaluasi program PUG Provinsi Jawa Barat; p) Sosialisasi dan Pelatihan Bagi Tenaga Pendidik dan Tenaga Kependidikan

Di dalam kegiatan-kegiatan di atas Dinas Pendidikan memasukkan peningkatan pemahaman dan kesadaran unsur pendidikan terhadap perdagagangan manusia. Khususnya, pemahaman atau sosialisasi kepada para guruguru dan kepala sekolah agar dapat mencegah terjadinya perdagangan manusia. Program tersebut didasarkan pada pertimbangan bahwa sebagian anak korban trafficking berstatus pelajar. Melalui sosialisasi tersebut diharapkan bahwa kepala sekolah dan guru BP dapat mensosialisasikannya kepada guru dan siswa sekolah, sehingga pada gilirannya diharapkan dapat mencegah dan menekan angka trafficking usia sekolah di Jawa Barat. Program tersebut dilaksanakan sejak tahun 2009 dan masih dilaksanakan sampai saat ini. Dalam program sosialisasi, para guru (peserta) memperoleh pelatihan mengenai pengertian, bentuk, penyebab dan penanganan perdagangan manusia. Pelatihan dilaksanakan 1 kali dalam satu tahun ajaran sekolah. Selain sosialisasi, setiap sekolah dianjurkan memasang leaflet-leaflet tentang bahaya trafficking. Program tersebut diselenggarakan melalui bidang Pendidikan Non Formal dan Informal (PNFI). Pendanaan program bersumber dari APBD Provinsi Jawa Barat namun jumlah anggaran tersebut dirasakan masih terbatas sehingga perlu ditingkatkan.

\section{Kebijakan Badan Pemberdayaan Perempuan, Kependudukan dan Keluarga Berencana Provinsi Jawa Barat}

Dalam prakteknya, peran BPPKB dalam perlindungan anak korban perdagangan manusia lebih bersifat koordinatif dan fasilitatif. Ini artinya, BPPKB tidak menjalankan fungsi teknis secara langsung dalam perlindungan sosial anak. Fungsi teknis penanganan anak korban trafficking dilaksanakan oleh Pusat Pelayanan Terpadu Pemberdayaan Perempuan dan Anak (P2TP2A) Provinsi Jawa Barat. Tugas pokok BPPKB dalam penanganan trafficking terkait dengan perumusan kebijakan/regulasi, pencegahan dan peningkatan kapasitas kelembagaan dalam pencegahan dan penanganan trafficking, termasuk trafficking anak. 
Sebagai lembaga non-teknis, BPPKB banyak menjalankan peran fasilitator dan koordinasi dalam pelaksanaan tugasnya. Dalam pelaksanaan fungsinya, BPPKKB melakukan kerjasama dan koordinasi dengan lembaga/dinas terkait di lingkup provinsi seperti Dinsos, Dinkes, Kepolisian, Disdik , P2TP2A Jawa Barat dan sebagainya: pemerintah Kabupaten/Kota di Jawa Barat; pemerintah provinsi lainnya; Kementrian terkait, khususnya Kementrian Pemberdayaan Perempuan dan Perlindungan Anak; lembagalembaga non-pemerintah tingkat nasional dan internasional seperti Komnas Perempuan, Komnas Anak, International Organisation for Migration, International Catholic Migration Commission; serta pusat kajian perempuan dan anak di lingkungan perguruan tinggi. BPPKKB juga baru saja mengembangkan kerjasama dengan unsur TNI Bintara Pembina desa (Babinsa) di 5 kabupaten dalam pencegahan dan penanganan perdagangan orang.

Pendanaan kegiatan bersumber dari dana APBD dan dana dari donor, khususnya lembaga-lembaga internasional yang memiliki perhatian terhadap isu perdagangan manusia. Misalnya pada tahun 2012, APBD Jawa Barat untuk menangani masalah kekerasan terhadap perempuan dan anak (termasuk peragangan manusia) mencapai 30 milyar yang disebar ke P2TP2A, Badan Pemberdayaan Perempuan dan Keluarga Berencana (BPPKB), Gugus Tugas Pencegahan, Dinas Koperasi dan Usaha Kecil dan Menengah (KopKUKM), Dinas Pendidikan (Disdik), Dinas Perindustrian dan Perdagangan (Disperindag), dan Penanganan Tindak Pidana Perdagangan Orang.

\section{Unit Perlindungan Perempuan dan Anak Polda Jawa Barat}

Penanganan permasalahan perdagangaan manusia khususnya perempuan dan anak di Polda Jawa Barat ditangani oleh Unit Trafficking dan Penyelundupan Orang. Adapun kebijakan terkait dengan perlindungan dan penanganan anak korban trafficking di Polda Jawa Barat yang dilaksanakan sejak tahun 2006 meliputi: a) Preemtif; bertujuan untuk menimbulkan daya tangkal sejak dini sehingga tidak terpengaruh oleh bujuk rayu dari para calo penyalur tenaga kerja wanita dan anak secara illegal melalui berbagai penyuluhan; b) Preventif; dengan tujuan guna mencegah lalu lintas manusia yang diperdagangkan secara illegal dari desa ke kota maupun dari satu kota ke kota lain dan dari dalam negeri ke negara tujuan. Hal ini dilakukan dengan melakukan pengawasan secara ketat di tempat penampungan / kos dan tempat lain yang dapat diperkirakan dapat melancarkan lalu lintas perdagangan wanita dan anak seperti pelabuhan laut, pelabuhan udara, pintu gerbang perbatasan dengan negara lain dan patroli di perairan untuk mengawasi kapal perahu yang diduga membawa tenaga kerja korban perdagangan manusia; c) . Represif dengan tujuan untuk menanggulangi setiap kejahatan terhadap perdagangan wanita dan anak serta menangkap para pelaku dan mengungkapkan jaringan untuk diproses secara hukum yang berlaku dengan melakukan kegiatan raziadi tempat penampungan wanita dan anak, tempat pelacuran tempat hiburan, pelabuhan peti kemas, pemeriksa kapal atau perahu di daerah perairan dan pelabuhan udara. Terkait pendanaan, kegiatan di UPPA Polda Jabar bersumber dari APBN.

Terkait dengan penanganan kasus, korban dan pelaku dilakukan dalam Unit Pelayanan Perempuan dan Anak (UPPA). Tugas UPPA adalah memberikan pelayanan dalam bentuk perlindungan terhadap perempuan dan anak yang menjadi korban kejahatan/kekerasan dan penegakan hukum terhadap pelakunya. Termasuk di dalamnya: menerima laporan/pengaduan tentang tindak kekerasan terhadap perempuan dan anak (termasuk perdagangan orang); membuat laporan polisi; -memberikan konseling, mengirimkan/merujuk korban ke Pusat Pelayanan Terpadu (PPT) atau Rumah Sakit terdekat; -melakukan penyidikan perkara, termasuk permintaan Visum et Repertum; memberikan kepastian kepada pelapor, bahwa akan ada tindak lanjut dari laporan / pengaduan; -menyalurkan korban ke Lembaga Bantuan Hukum (LBH) atau Rumah Aman, 
apabila diperlukan; -mengadakan koordinasi/ kerjasama dengan lintas fungsi/instansi, pihak yang terkait; dan menginformasikan perkembangan penyidikan kepada pelapor.

\section{ANALISA}

Provinsi Jawa Barat telah memiliki Perda Pencegahan dan Penanganan Korban Perdagangan Orang . Peda tersebut merupakan turunan dari Undang-undang Penghapusan Tindak Pidana Perdagangan Orang karena mengatur tanggung jawab dan kewenangan pemerintah daerah provinsi Jawa Barat dalam pencegahan dan penanganan korban trafficking. Dari segi substansi, walaupun Perda tersebut memayungi Pencegahan dan Penanganan Korban Perdagangan Orang secara umum, terdapat aturan yang khusus mengatur pencegahan pekerjaan terburuk anak. Anak yang menjadi korban trafficking seringkali dieksploitasi dalam sektor pekerjaan terburuk anak termasuk pornografi, pelacuran, dan sebagainya. Peraturan tersebut juga mengatur kewajiban pemerintah daerah dalam memberikan pelayanan kepada korban tindak pidana perdagangan orang serta mengatur tanggungjawab masing-masing unsur pemerintah dalam penanganan korban, termasuk anak korban trafficking. Perda tersebut menjadi acuan bagi lembaga pemerintah yang ditunjuk untuk merancang dan melaksanakan kebijakan/program yang dibutuhkan.

Dilihat dari tujuannya, sebagian besar program/kegiatan perlindungan anak korban trafficking di Jawa Barat bertujuan rehabilitatif yaitu membantu korban trafficking mengatasi dampak-dampak negative yang dialami sebagai korban pada aspek fisik, mental dan sosial, umumnya melalui pelayanan rehabilitasi dan pelayanan yang ramah anak. Pelayanan rehabilitasi umumnya dilakukan melalui Dinas Sosial sedngkan penanganan hukum oleh UPPA Polda.

Ditemukan juga kegiatan-kegiatan yang berujuan untuk mencegah anak diperdagangkan kembali. Kegiatan reintegrasi korban dan penguatan ekonomi keluarga Dinas Sosial misalnya ditujukan untuk mengurangi kerentanan korban dan keluarga korban terhadap terulangnya trafficking. Bantuan bagi anak korban (terutama golongan tidak mampu) untuk melanjutkan pendidikan bukan saja bermaksud untuk mengintegrasikan korban ke lingkungan yang sesuai dengan tahap perkembangannya tapi juga mengurangi resiko untuk mengalami retrafficking. Pendidikan merupakan faktor pelindung karena banyak korban trafficking adalah mereka yang memiliki pendidikan rendah dan tidak memiliki pengetahuan yang memadai tentang praktek perdagangan manusia. Pelatihan keterampilan, sistem magang dan penyaluran kerja bagi anak korban yang dilakukan oleh Dinas Sosial juga meningkatkan daya tawar anak dan dapat mencegah mereka diperdagangkan kembali. Berbagai data empirik menunjukkan bahwa korban trafficking umumnya diiming-imingi pekerjaan dengan upah tinggi. Keterbatasan kondisi ekonomi dan keterbatasan lapangan kerja bagi masyarakat dengan tingkat keterampilan rendah seringkali menjadi faktorfaktor yang dapat meningkatkan resiko menjadi korban trafficking.

Program-program berupa sosialisasi mengenai trafficking yang dilaksanakan oleh Dinas Pendidikan, BPPKKB, dan Kepolisian Jawa Barat dapat digolongkan bertujuan mencegah retrafficking. Walaupun pada prinsipnya program-program tersebut bermaksud mencegah terjadinya trafficking dengan memberikan informasi mengenai bahaya dan mosus perdagangan anak, hal tersebut juga berdampak tidak langsung untuk mencegah retrafficking. Sosialisasi dapat meningkatkan pemahaman dan kewaspadaan korban dan keluarga korban untuk menghindari terjadinya retrafficking.

Tujuan-tujuan program/kebijakan yang dibentuk merupakan respons terhadap masalah perdagangan manusia di Jawa Barat. Pertama, tingginya angka korban trafficking asal Jawa Barat dan tantangan yang besar untuk memecahkan masalah tersebut mengharuskan pemerintah daerah untuk merespon secara tepat isu tersebut.Program-program yang bersifat pencegahan dilatarbelakangi motivasi 
untuk mengurangi kerentanan anggota masayarakat terhadap praktek trafficking. Kedua, korban trafficking, khususnya anak yang diperdagangkan bukan hanya dirampas haknya untuk bebas dari tindak kekerasan, tapi juga mengalami dampak negative multidimensi yang dapat menghambat tumbuh kembangnya secara wajar. Dengan demikian perlu dilakukan pelayanan-pelayanan untuk membantu korban mengatasi dampak negative yang dialaminya.

Namun demikian kajian ini tidak menemukan kebijakan/program yang bertujuan memantau kondisi dan perkembangan anak korban perdagangan manusia dan keluarganya. Meskipun pencatatan dilakukan pada saat korban mendapatkan pelayanan, tidak ada tidak lanjut untuk memonitor kondisi korban dan keluarganya secara khusus dalam jangka tertentu. Tidak ada monitoring setelah korban menjalani reintegrasi, merefleksikan suatu asumsi bahwa reintegrasi berjalan dengan sebagaimana mestinya dan telah terjadi perubahan positif pada korban dan keluarganya. Padahal faktor-faktor resiko dan faktor-faktor pelindung yang berasal dari dalam diri maupun lingkungan korban anak berbeda-beda sehingga daya tangkal terhadap kemungkinan re-trafficking antara individu korban satu dengan lainnya berbeda-beda.

Selain itu, program-program yang ditujukan untuk meningkatkan peran serta dan kemampuan orangtua dalam pengasuhan dan perawatan anak belum mendapat perhatian. Program-program untuk penguatan keluarga umumnya hanya ditujukan untuk penguatan ekonomi. Padahal kemampuan pengasuhan, termasuk di dalamnya pengawasan anak, pemberian dukungan kepada anak yang menjadi korban trafficking dan sebagainya merupakan salah satu aspek penting dalam perlindungan anak korban, temasuk untuk meningkatkan daya tangkal anak dan mencegah retrafficking.

Berdasarkan basis alokasinya, program/kebijakan perlindungan sosial anak korban trafficking pada umumnya dapat digolongkan sebagai program-program yang bersifat selektif. Hal ini karena sasaran program umumnya ditujukan kepada korban dan atau keluarga korban (attributed needs). Penjemputan korban, rehabilitasi psiko-sosial, penanganan kasus dan perlindungan melalui kepolisian umumnya hanya diberikan kepada korbansaja. Kriteria tersebut merupaan hal yang wajar mengingat perlindungan korban merupakan hal yang prioritas dan spesifik.

Sementara itu kriteria-kriteria tambahan penerimaan pelayanan dapat dilihat pada beberapa program lainnya. Misalnya, kondisi sosial-ekonomi keluarga melalui means-tested merupakan indikator tambahan dalam program pemberdayaan ekonomi keluarga melalui Usaha Ekonomi Produktif dan penyaluran fasilitas Jaminan Kesehatan Keluarga Miskin. Kedua program ini dikhususkan bagi korban dan keluarga korban yang berasal dari kelompok miskin saja. Sementara itu pelatihan keterampilan melalui Program Bina Remaja menambahkan kriteria usia dan attributed needs sebagai prasyarat untuk mendapatkan pelayanan. Para peserta pelatihan adalah anak berusia remaja, mengalami putus sekolah serta bersedia untuk mendapatkan pelatihan keterampilan kerja..

Yang menjadi pertanyaan adalah bagaimana dengan pelayanan korban trafficking yang tidak berasal dari keluarga miskin atau tidak memenuhi kriteria-kriteria tambahan lainnya? Jika kebanyakan pelayanan diasosiasikan sebagai pelyanan bagi anak korban trafficking yang tidak mampu, bukankah nantinya hal tersebut menciptakan stigma bagi pelayanan-pelayanan tersebut? . Sebaliknya, kriteria eligibilitas penerima pelayanan yang berfokus pada kelompok miskin seakan-akan mengasumsikan bahwa korban yang berasal dari kelompok mampu tidak memerlukan pelayanan atau tidak layak dibantu. Kriteria tambahan sebagai dasar penentuan eligibilitas bisa saja diperluas, misalnya didasarkan pada tingkat keparahan kasus trafficking dan dampaknya pada korban mengingat bahwa kebutuhan korban yang mengalami kasus atau dampak berat akan berbeda dengan mereka yang mengalami kasus atau dampak yang relative lebih ringan. 
Program-program perlindungan anak korban trafficking menyediakan manfaat dalam berbagai bentuk. Perlindungan secara langsung diberikan kepada korban berupa untuk menghentikan viktimisasi korban, merehabilitasi korban untuk mengurangi dampak fisik, psikologis dan sosial yang dialami korban sehingga membantu korban untuk dapat berfungsi secara normal, dan mereintegrasikan korban ke dalam lingkungan asal dan lingkungan sosial yang lebih luas.Penghentian viktimisasi dilakukan dengan cara menjemput korban dari lokasi kejadian trafficking dan membawa korban ke tempat yang aman di mana ia mendapatkan bantuan dan perlindungan. Sementara itu bentukbentuk manfaat dari kegiatan-kegiatan rehabilitasi berupa:

a. pemberian pelayanan profesional (termasuk rujukan) seperti terapi untuk mengatasi efek trauma, konseling, pelayanan dan perawatan kesehatan

b. peraturan perlindungan (protective regulation) berupa hak-hak istimewa sebagai korban anak seperti adanya pendampingan khusus dalam proses penyidikan, standar khusus dalam pemeriksaan/penyidikan petugas kepolisian

Sementara itu perlindungan yang secara tidak langsung diberikan merupakan bentukbentuk pelayanan yang tujuannya bisa diperluas untuk mencegah terjadinya retrafficking baik dengan cara mengurangi kerentanan korban, mengurangi kerentanan keluarga, dan kerentanan masyarakat. Termasuk di dalamnya pencegahan trafficking yang dilaksanakan oleh Dinas Pendidikan dan BPPKB dalam bentuk sosialisasi kepada masyarakat umum.

Bentuk-bentuk manfaat yang ditawarkan dalam program-program yang bersifat pencegahan retrafficking misalnya dapat dilihat dari program pemberdayaan ekonomi keluarga dan asuransi kesehatan untuk keluarga miskin. Dilihat dari bentuknya, bantuan yang diberikan dalam pemberdayaan ekonomi keluarga korban berupa barangbarang modal usaha (goods) sementara jaminan kesehatan keluarga miskin dapat digolongkan sebagai subsidi.

Yang menjadi pertanyaan apakah bentuk-bentuk pelayanan tersebut efektif untuk mencapai tujuannya? Misalnya, pemberian bantuan pelatihan keterampilan dan modal usaha kepada keluarga korban melalui UEP. Program UEP didesain untuk tujuan membantu meningkatkan kemampuan ekonomi keluarga korban yang berasal dari kelompok miskin hanya dalam jangka waktu satu tahun. Namun demikian lemahnya pendampingan, rendahnya motivasi dan keterampilan penerima bantuan ditenggarai menyebabkan penerima bantuan tidak dapat menjaga kesinambungan usahanya sehingga kembali mengalami kesulitan ekonomi. Kondisi ini tentu saja merupakan faktor resiko tersendiri karena kesulitan ekonomi memberikan pilihan-pilihan terbatas bagi keluarga. Desain program UEP tampaknya perlu disempurnakan melalui penguatan pendampingan dan pelatihan keterampilan yang lebih memadai.

Kajian ini juga menemuan bahwa tidak ada satupun dari program perlindungan korban yang memberikan pelayanan berupa uang tunai (cash), setidaknya dalam jangka waktu tertentu. Keberadaan program berupa pemberian pelayanan berbentuk uang tunai tampaknya akan memberikan keleluasaan yang lebih besar bagi korban dan keluarga korban dalam pemenuhan kebutuhan dasarnya. Program Kesejahteraan Sosial Anak dari Kemensos yang menyediakan bantuan tunai kepada anak-anak yang berisiko sosial ekonomi tampaknya dapat dikembangkan untuk menjangkau anak-anak korban trafficking.

Dilihat dari sumber pendanaan, program-program perlindungan anak korban trafficking berasal dari berbagai sumber. Sumber-sumber yang regular berasal dari dari APBN dan APBD. Dana-dana APBN dan APBD ini dapat dikatakan bersifat lebih kaku, dengan kata lain pendanaan diberikan untuk kegiatan-kegiatan yang berbasis program, yang diajukan setiap tahun. Mekanisme ini kurang memungkinkan untuk terjadinya 
perubahan program di tengah tahun anggaran. Ini berarti bahwa untuk pendanaan berbasis program dapat menghambat pendanaan kegiatan-kegiatan tertentu yang kebutuhan penganggarannya bersifat tidak dapat diprediksi. Dalam konteks perlindungan korban trafficking ditenggarai banyak kebutuhan pendanaan yang sifatnya tidak terstruktur/tidak diduga.

Kajian ini menemuan bahwa para pembuat dan pelaksana kebijakan perlindungan sosial anak merasakan bahwa pendanaan kegiatan sangat kurang sehingga mempengaruhi efektivitas program. Hasil observasi misalnya menunjukkan bahwa kegiatan penjemputan korban trafficking asal Jawa Barat hampir selalu dapat dilakukan manakala diperlukan. Namun demikian, pendanaan untuk program-program lainnya tidak selalu tersedia manakala dibutuhkan sehingga pemenuhannya harus ditunda. Bantuan UEP bagi keluarga korban misalnya tidak bisa langsung diberikan jika ternyata diajukan setelah usulan penganggaran diajukan ke Kementrian Sosial. Akibatnya, keluarga korban kadang terpaksa harus menunggu diusulkan pada tahun anggara berikutnya. Hal ini tentulah dapat mengakibatkan dampak negatif bagi keluarga korban, terutama jika penguatan ekonomi melalui pemberian bantuan mendesak diperlukan.

Sementara itu pendanaan yang berasal dari donor bersifat tidak tetap sehingga kurang dapat diandalkan kelanjutannya. Tampaknya lembaga/dinas terkait dengan teknis pelayanan anak korban trafficking dapat melakukan diversifikasi sumber pendanaan, misalnya bekerjasama dengan sektor swasta di dalam negeri untuk membiayai program-program perlindungan anak korban trafficking. Misalnya, program Corporate Social Responsibility khusus untuk pemberdayaan ekonomi keluarga, yang di dalamnya juga melibatkan keluarga korban; program pelatihan, magang dan rekruitmen anak korban trafficking yang memilih untuk bekerja, dan sebagainya.

\section{KESIMPULAN DAN REKOMENDASI}

Kebijakan payung perlindungan sosial anak korban trafficking di Jawa Barat termuat dalam Peraturan Daerah tentang Pencegahan dan Penanganan Korban Perdagangan Manusia tahun 2008. Peraturan tersebut menegaskan fungsi berbagai lembaga pemerintah daerah dalam mencegah trafficking serta menangani korban. Namun demikian, pembasahan terkait retrafficking tampaknya luput dari Perda dimaksud meskipun sangat mungkin bagi korban untuk menggalami retrafficking.

Jenis kebijakan/program yang dirancang dan dilaksanakan oleh Dinas/Lembaga terkait yang menjadi sasaran dalam penelitian ini memiliki tujuan yang beragam: pre-emtif, preventif, rehabilitative, dan reintegratif. Keempat domain tujuan tersebut sangat esensial dalam perlindungan sosial karena tidak hanya ditujukan bagi korban tapi juga keluarga korban dan masyarakat pada umumnya. Mengingat besarnya pengaruh lingkungan terhadap resiko seseorang untuk menjadi korban trafficking, kebijakan yang berorientasi pada penguatan lingkungan hidup anak atau penciptaan lingkungan hidup anak yang protektif menjadi sangat esensial. Demikian pula halnya dengan program-program rehabilitative yang mengembalikan keberfungsian korban. Namun demikian, kebijakan/program yang ada belum merefleksikan pentingnya monitoring kondisi korban dan lingkungannya. Mengingat faktorfaktor resiko dan faktor-faktor pelindung yang berasal dari dalam diri maupun lingkungan korban anak berbeda-beda maka perkembangan atau perubahan korban dan lingkungan serta daya tangkal terhadap kemungkinan re-trafficking antara individu korban satu dengan lainnya berbeda-beda. Monitoring diperlukan untuk dapat mengamati perubahan sasaran kebijakan sekaligus mengantisipasi gangguan atau hambatan terhadap peningkatan kondisi dan keberfungsian korban dan lingkungan.

Selain itu, program-program yang ditujukan untuk meningkatkan peran serta dan kemampuan orangtua dalam pengasuhan dan 
perawatan anak belum mendapat perhatian. Program-program untuk penguatan keluarga umumnya ditujukan untuk penguatan ekonomi. Padahal kemampuan pengasuhan, termasuk di dalamnya pengawasan anak, pola komunikasi, pemberian dukungan kepada anak yang menjadi korban trafficking dan sebagainya merupakan salah satu aspek penting dalam perlindungan anak korban, temasuk untuk meningkatkan daya tangkal anak dan mencegah retrafficking.

Basis alokasi program perlindungan umumnya mengacu pada kriteria terbatas yaitu attributed needs dan means tested. Kriteria tersebut, khususnya means-tested merefleksikan asumsi bahwa pelayanan hanya dibutuhkan oleh kelompok dengan tingkat pendapatan tertentu (miskin) sehingga dapat mengekslusi korban yang tidak memenuhi kriteria dimaksud serta memunculkan stigma terhadap program.

Bentuk manfaat yang disediakan dalam program sangat beragam, mulai dari protective regulation, pelayanan profesional, subsidi, dan bantuan barang. Bentuk manfaat uang tunai (cash) tidak ditawarkan bagi koban dan keluarganya meskipun bentuk manfaat tersebut memberikan keleluasan pemanfaatan bagi para penerima. Manfaat program diberikan dalam waktu yang terbatas dan seragam sehingga efektivitasnya dipertanyakan mengingat keragaman profil korban, keluarga korban, permasalahan, dan potensinya merefleksikan adanya perbedaan kebutuhan dan peluang dalam mencapai perubahan. Pemenuhan kebutuhan dasar anak korban harus menjadi prioritas sehingga design program perlu mempertimbangkan sejauh mana pemenuhan kebutuhan dasar anak di dalam keluarganya dapat dicapai.

Pendanaan kebijakan/program terbatas mengingat perlindungan anak korban trafficking bergabung dengan pendanaan untuk bentuk-bentuk perlindungan anak lainnya, termasuk anak korban tindak kekerasan rumah tangga, kekerasan public dan sebagainya. Sifat pendanaan yang umumnya berorientasi pada program dapat membatasi jangkauan program, sehingga dapat menghambat akses korban/keluarga korban.

. Rekomendasi yang diajukan dari penelitian ini adalah sebagai berikut.Orientasi kebijakan pada pencegahan retrafficking perlu diintegrsikan karena akan memberikan manfaat positif, terutama dalam memperluas cakupan kebijakan serta mengarahkan para pelaksana kebijakan dalam merancang kegiatan. Hal ini mengingat bahwa untuk mencegah retrafficking diperlukan design program/kebijakan yang lebih antisipatif dan komprehensif serta pelaksanaan yang lebih terarah dan efektif.

Program-program yang mengarah pada upaya monitoring dan penguatan kapasitas keluarga dalam pemenuhan kebutuhan mentalpsikologis dan spiritual anak perlu dikembangkan, selain program-program yang berorintasi pada pemberdayaan ekonomi. Perlu dilakukan diversifikasi jenis dan bentuk pelayanan untuk mengakomodir keberagamanan latar belakang korban baik dari aspek sosial ekonomi, tingkat keparahan kasus/dampak yang dialami, dan sebagainya. Selain program-program yang bersifat selektif, perlu dikembangkan program yang bersifat lebih universal sehingga mengurangi stigma bagi penerimanya. Selain itu, perlu adanya diversifikasi pendanaan, termasuk dengan cara kolaborasi bersama perusahaan swasta. Pendanaan program dapat dilakukan dengan mengintegrasikannya sebagai bagian dari program Corporate Social Responsibility.

\section{DAFTAR PUSTAKA}

Bowes, Jennifer M. Bowes \& Alan Hayes (ed). 1999. Children, Families, and Communities. Context and Consequences. Victoria: Oxford University Press.

Chambers, D.E. \& Wedel, K.R. (2005). Social policy and social programs: A method for the practical public policy analyst. ( $4^{\text {th }}$. ed.). Boston: Pearson.

.Dominelli, Lena. 1999. Community Approaches to Child Welfare: International Perspectives. England: Ashgate Publishing Limited. 
Ebbe, N, Obi, K dan Dilip, D. 2008. Global Trafficking in Women and Children. London: CRS Press.

Gilbert, N. \& Terrell, P. (2008). Dimensions of Social Welfare Policy (6 ${ }^{\text {th }}$ ed.). Boston: Allyn and Bacon.

International Organization for Migration. 2012. Trafficking in Indonesia: Severity dan Victim Profile. IOM-Indonesia: Jakarta

Leedy Paul \& Jeanne E. Ormrod. 2005. Practical Research: Planning and Design Research. Ohio: Pearson.

Mulyanto. 2004. Melacur Demi Hidup Fenomena Perdagangan Anak Perempuan di Palembang. Yogyakarta: Pusat Studi Kependudukan dan Kebijakan Universitas Gadjah Mada.

Spicker, Paul. 1995. Social Policy, Themes and Approach. London: Prentice Hall.
Shireman, Joan. 2003. Critical Issues in Child Welfare. New York: Columbia University Press.

Suharto, Edi. 2005. Membangun Masyarakat Memberdayakan Rakyat. Bandung: Refika Aditama.

--------------. 2000. Pembangunan Kebijakan Sosial dan Pekerjaan Sosial. Bandung: LSP-STKS Bandung.

Publik. Bandung: Alfabeta.

Sumber lain:

Convention on The Right of the Child (1989) Undang-Undang RI Tentang Perlindungan Anak

Undang-Undang RI tentang Pemberantasan Tindak Pidana Perdagangan Orang Perda Jabar No. 3 tahun 2008 